\title{
VOCATIONAL HIGH SCHOOL STUDENTS' ANGER MANAGEMENT SKILL
}

\author{
Anifa Tuzzuhroh Nurbaiti*, Budi Astuti, Prisa Sari Yantika \\ *Correspondent Author
}

\author{
Anifa Tuzzuhroh Nurbaiti \\ Universitas Negeri Yogyakarta, \\ Indonesia \\ Jalan Colombo No. 1, Kabupaten \\ Sleman, Daerah Istimewa Yogakarta, \\ 55281 \\ Indonesia \\ anifatuzzuhroh.2019@student.uny.ac.id \\ Budi Astuti \\ Universitas Negeri Yogyakarta, \\ Indonesia \\ Jalan Colombo No. 1, Kabupaten \\ Sleman, Daerah Istimewa Yogakarta, \\ 55281 \\ Indonesia \\ budi_astuti@uny.ac.id \\ Prisa Sari Yantika \\ Universitas Negeri Yogyakarta, \\ Indonesia \\ Jalan Colombo No. 1, Kabupaten \\ Sleman, Daerah Istimewa Yogakarta, \\ 55281 \\ Indonesia \\ prisasaris.2019@student.uny.ac.id
}

Halaman

92-97

\section{INTRODUCTION}

Anger is one of the avoided emotions. Viewed as one of three basic human emotions (McClellan, J., Levitt, K., \& DiClementi, G., 2017), anger is defined as a destructive emotion related to certain problems and sadness (Lök, N., Bademli, K., \& Canbaz, M., 2018). It is also viewed as a subjective emotion involving psychological and cognitive components (Kannis-Dymand, L., Salguero, J. M., Ramos-Cejudo, J., \& Novaco, R. W., 2019) and a negative feeling with cognition, psychological changes, and behavioral reactions (Lotfali, S., Moradi, A., \& Ekhtiari, H., 2016). Individuals, including adolescents, may experience anger.

As an individual, adolescents have several developmental tasks that should be done in each stage of their development.
Vocational high school students, ranging from 16 to 18 years old, undergo what is known as the late adolescence stage. During this stage, they experience some emotional changes metaphorically depicted as the storm period (Rahmi, 2017). Scholars recognize this period as heightened emotionality, a period in which adolescents' emotion is unstable. During this transitional stage, they are prone to anger.

According to Wigati (2013), two factors may lead to anger, namely physical and psychological factors. The former includes excessive fatigue, lack of certain substances, and hormonal matters. Meanwhile, the latter is closely related to individuals' personalities shaped by their environment. This factor emerges due to the presence of an inappropriate self-concept. An inappropriate self-concept may result in an imbalanced, 
immature personality. Some studies reveal a relationship between social acceptance and adolescents' anger, proving that adolescents who experience rejection tend to express their anger easier (Moore, C. C., Hubbard, J., Morrow, M. T., Barhight, L. R., Lines, M. M., Sallee, M., \& Hyde, C. T., 2019).

Anger is the most avoided emotion (McClellan, J., Levitt, K., \& DiClementi, G., 2017) since it may result in a range of harmful impacts on individuals. Wigati, I. (2013) states that anger may jeopardize one's health, trigger psychological disorders, and harm social relationships. In the same vein, Awaliyah, Taufiq, \& Hafina (2019) argue that anger could be expressed in various forms, such as verbal aggression or self-physical harm.

Poor anger management may adversely individuals, leading to various negative impacts, including aggressiveness. In a study conducted by Nasir and Ghani (2014), 1162 male and female students reported that they had experienced anger, and when feeling angry, $7.1 \%$ of them hit other people, $25.1 \%$ of them hit objects, $27.8 \%$ express it verbally, and $50 \%$ of them said that they regret their anger expression. Some cases are reported due to poor anger management. Poor anger management could be harmful when it is not controlled.

Anger does not necessarily result in a negative effect. According to Tefrate, Kassinove, \& McKay (2019), anger could be viewed as a positive thing since it indicates the presence of a problem, it could motivate self-changes, and drives an individual to face a problem. Anger could be viewed as a healthy emotion when it could be properly managed (Cherry \& Flanagan, 2017).

According to Bilge, A., \& Keskin, G. (2017), anger management refers to an individual's efforts made to express or control anger. Anger management does not only mean repressing the emotion but also balancing the emotion. Accordingly, it serves as one of the keys to emotional well-being. By having proper emotional management, individuals could express their anger positively (Bhave \& Saini, 2009). Utami and Elfina's (2018) study proves that anger management could overcome aggression in adolescents. It is also supported by Siddiqah (2010), who found that anger management may prevent and control adolescents' aggressive behavior. In the same vein, Hudaya (2015) found that anger management could enhance students' anger management in Class $\mathrm{X}$ of Computer and Network Engineering in SMK Muhammadiyah 1 Moyudan.

Our observation in class $X$ of SMK Muhammadiyah Mungkid showed that some students lack anger management. Some of them stated that they found it difficult to control their emotions, which adversely affects their academic activities. They stated that they prefer to express their anger through fighting, crying, and skipping class. Since these problems are related to students' anger management, particularly in Class $X$ SMK Muhammadiyah Mungkid, school counselors should provide a service to solve these problems. However, prior to the provision of service, it is necessary to find out the level of students' anger management to provide a proper guidance and counseling service.

School counselors' role is important in helping students to manage their anger without ignoring their developmental tasks. As described by Sukmawati, Neviyarni, Syukur, and Said (2013), guidance and counseling functions to help individuals to understand themselves and their surroundings, prevent problems that potentially hinder their development, and solve a problem by developing their potentials. In line with Sukmawati et al. (2013), Tohirin states that guidance and counseling is a professional helping process provided by a counselor for his/her clients to make them aware of their problems and solve them. The result of the present study is expected to serve as a foundation for school counselors to design a guidance and counseling program and technique to improve students' anger management skills.

\section{METHODS}

This descriptive study involved 282 students of Class X in SMK Muhammadiyah Mungkid. They were recruited using a simple random sampling technique from the total population of 540 students. In collecting the data, and anger management scale was employed. Expert judgment was used to validate the instrument. 36 items of the instrument were considered valid by the expert. Regarding the instrument reliability, Cronbach's alpha coefficient of the instrument was 0.86, indicating high reliability. The collected data were analyzed descriptively. 


\section{4 | PSIKOPEDAGOGIA}

JURNAL BIMBINGAN DAN KONSELING

Vol.9, No.2, December 2020

\section{RESULT AND DISCUSSION}

The data analysis describes the students' anger management based on some aspects, namely, recognizing anger, controlling anger, relieve anger, and assertively expressing anger. Table 1 displays the students' anger management skills based on all aspects of anger management.

\section{Table 1}

Students' overall anger management skill
No Categor Score Frequency Percentag

\begin{tabular}{ccccc} 
& $\begin{array}{c}\text { Categor } \\
\text { y }\end{array}$ & Score & Frequency & $\begin{array}{c}\text { Percentag } \\
\mathrm{e}\end{array}$ \\
\hline 1. & Very & $118-144$ & 170. & 60.3. \\
& High & & & \\
2. & High & $100-117$ & 72. & 25.5. \\
3. & Moderat & $80-99$ & 36. & 12.8. \\
& e & & & \\
4. & Low & $73-81$ & 4. & 1.4. \\
5. & Very & $0-73$ & 0. & 0. \\
& Low & & 282. & 100. \\
\hline
\end{tabular}

As displayed in Table 1, most of the students' $(60.3 \%)$ overall anger management skill was categorized as very high. However, four students were reported to have low anger management skills.

This result implies that most students have possessed good anger management. Anger management is pivotal to relieve anger and reduce aggressive behavior (Valizadeh, Davaji, \& Nikamal, 2010). A study conducted by Rahayu \& Soejuwinoto (2017) found that understanding anger management could improve students' anger management skills.

Anger management is pivotal, as indicated by Lee \& DiGuisppe (2018), who found that anger management is effective for relieving anger and aggressive behavior. Their finding is supported by Amin and Khawar (2018), who found that anger management allows students to control students' anger and aggressive behavior.

Anger may result in various negative effects. It serves as a general factor of adolescents' homicide and suicide cases (Pullen, Sandra, Lane, Kearnely, \& Engle, 2015). It is important to enhance students' anger management skills to prevent such negative effects and reduce adolescents' aggressive behavior (Siddiqah, 2010). The measurement of adolescents' anger management skills is useful to help them deal with anger. Feindler and Engel (2011) state that anger management skill measurement allows individuals to provide proper interventions in school settings. In line with it, Shahsavarani and Noohi (2014) state that anger should be studied in various communities, particularly students. Table 2 displays the students' anger management skills based on one of the aspects of anger management, namely anger recognition.

\section{Table 2}

Students' anger recognition skill

\begin{tabular}{ccccc}
\hline No & Category & Score & Frequency & Percentage \\
\hline 1. & Very High & $40-48$ & 53. & 18.8. \\
2. & High & $34-39$ & 134. & 47.5. \\
3. & Moderate & $28-33$ & 86. & 30.5. \\
4. & Low & $22-27$ & 9. & 3.2. \\
5. & Very Low & $0-21$ & 0. & 0. \\
& Total & & 282. & 100. \\
\hline
\end{tabular}

As displayed in Table 2, most of the students' $(47.5 \%)$ anger recognition skill was categorized as very high. This result indicates that the majority of the students in this study were capable of recognizing their anger properly. However, nine students were reported to have low anger recognition skills.

This result indicates that most students fail to recognize their anger, whereas Reily and Shopshire (2019) state that the most important component of anger management is to recognize the main feeling that leads to anger. It is also supported by Gentry (2007), who states that anger management is related to giving one's self-time to examine the reason for his/her anger and to choose an appropriate response to the anger. Anger, as one of the basic human feelings (Tefrate, Kassinove, \& McKay, 2019), Consists of four components, namely, thought, feeling, behavior, and physiological component (Sari, 2019). By recognizing these components, an individual may not be ruled by anger. Table 3 displays the students' anger management skills based on one of the aspects of anger management, namely anger control.

Table 3

Students' anger control skill

\begin{tabular}{|c|c|c|c|c|}
\hline No & $\begin{array}{c}\text { Categor } \\
y\end{array}$ & Score & Frequency & $\begin{array}{c}\text { Percent } \\
\text { age }\end{array}$ \\
\hline 1. & $\begin{array}{l}\text { Very } \\
\text { High }\end{array}$ & $40-48$ & 71. & 25.2 \\
\hline 2. & High & $34-39$ & 130. & 46.1 . \\
\hline 3. & $\begin{array}{c}\text { Moderat } \\
\mathrm{e}\end{array}$ & $28-33$ & 67. & 23.3. \\
\hline 4. & Low & $22-27$ & 13. & 4.6. \\
\hline 5. & $\begin{array}{l}\text { Very } \\
\text { Low }\end{array}$ & $0-21$ & 1. & 0.4 . \\
\hline & Total & & 282. & 100. \\
\hline
\end{tabular}

As displayed in Table 3 , most of the students' $(46.1 \%)$ anger control skills were categorized as very high. However, one student was reported to not able to control 
anger. This result implies that most students have a moderate level of anger control. Individuals who can control their emotions will not allow themselves to be ruled by anger. Anger may be triggered by many causes. According to Cherry \& Flanagan (2017), anger may be triggered by hurt feelings, unfair treatment, disobedience, and violation of rights. Uncontrollable anger may frequently lead to aggression. Utami and Elfina's (2018) study notes that aggressive behavior is worsened when individuals fail to manage their anger. Anger control is one of the important aspects of anger management. Tefrate, Kassinove, \& McKay (2019) state that the controlled anger may be transformed into a positive thing, such as an indication that something is not right, opportunity to change one's self, opportunity to not run away from a problem, and opportunity to make individual feels the spirit of life. Consistent with Tefrate and his associates, Reily and Shopshire (2019) also state that anger should be controlled since it may lead to negative consequences when it is not properly expressed. Table 4 displays the students' anger management skills based on one of the aspects of anger management, namely anger relief.

Table 4

Students' anger relief skill

\begin{tabular}{ccccc}
\hline No & $\begin{array}{c}\text { Categ } \\
\text { ory }\end{array}$ & Score & $\begin{array}{c}\text { Frequen } \\
\text { cy }\end{array}$ & $\begin{array}{c}\text { Percentag } \\
\text { e }\end{array}$ \\
\hline 1. & $\begin{array}{l}\text { Very } \\
\text { High }\end{array}$ & $15-16$ & 72. & 25.5. \\
2. & $\begin{array}{c}\text { High } \\
\text { 3. }\end{array}$ & $12-14$ & 0. & 0. \\
Moder & $10-11$ & 114. & 40.4. \\
& ate & & & \\
4. & Low & $8-9$ & 84. & 29.8. \\
5. & Very & $0-7$ & 12. & 4.3. \\
& Low & & 282. & 100. \\
\hline
\end{tabular}

As displayed in Table 4, 114 the students' $(40.4 \%)$ anger relief skill was categorized as moderate. Twelve students were reported to have very low anger relief skills. This result implies that most students have a moderate level of anger control. Anger relief is important in anger management. Mokhber, Masjedi, \& Bakhtiari's (2016) study shows that anger management training may significantly reduce adolescents' anger. Anger relief refers to an ability to calm down when feeling angry (Goleman, D., Boyatzis, R., \& McKee, A., 2002). There are various activities to relieve anger, such as sightseeing, exercising, or doing relaxation. In addition, anger can also be relieved by enhancing one's empathy. By enhancing empathy, according to Potter-Efron (2015), individuals can relieve anger emotion. Table 5 displays the students' anger management skills based on one of the aspects of anger management, namely assertive anger expression.

\section{Table 5}

Students' assertive anger expression skill

\begin{tabular}{ccccc}
\hline No & $\begin{array}{c}\text { Categ } \\
\text { ory }\end{array}$ & Score & $\begin{array}{c}\text { Frequen } \\
\text { cy }\end{array}$ & $\begin{array}{c}\text { Percentag } \\
\text { e }\end{array}$ \\
\hline 1. & Very & $26-32$ & 41. & 14.5. \\
& High & & & \\
2. & High & $23-26$ & 142. & 50.4. \\
3. & Moder & $19-22$ & 78. & 27.7. \\
& ate & & & \\
4. & Low & $15-18$ & 20. & 7.1. \\
5. & Very & $0-14$ & 1. & 0.4. \\
& Low & & 282. & 100. \\
\hline
\end{tabular}

As displayed in Table 5, most of the students' (50.4\%) assertive anger expression skill was categorized as high. However, some student was reported to not able to express their anger assertively. As table 5 displays, one student's assertive anger expression skill was categorized as very low.

This result implies that most students have not been able to express their anger assertively. Anger management is a means to identify the cause of anger and to train an appropriate response to the anger (Yunere, Keliat \& Putri, 2019). One of the responses trained in anger management is assertive anger expression. An assertive person can express their anger without hurting other people's feelings.

Goleman, D., Boyatzis, R., \& McKee, A. (2002) state that an assertive individual could establish proper communication and healthy relation with others. This is supported by Tefrate, Kassinove, \& McKay (2019), who state that one of the final steps of anger management is to express anger assertively. Consistent with Tefrate et al. (2019), Hudaya (2015) states that one of the modest strategies to manage anger is by using an "I" statement to emphasize an individual's perspective towards others. Assertive anger expression is done by stating an individual's desire to other people in order to create a better situation.

According to Potter-Effron (2015), anger expression can reduce anger that is caused by a feeling of helplessness and inability to control the critical situation. By expressing anger, individuals may learn to realize the limitations of their self-control, thus driving 


\section{6 | PSIKOPEDAGOGIA}

JURNAL BIMBINGAN DAN KONSELING

Vol.9, No.2, December 2020

them to act properly. Cherry and Flanagan (2017:13) state that anger is an emotion that can improve one's fitness. Thus, assertive anger expression allows individuals to reduce the negative impacts of anger.

\section{CONCLUSION}

Students' anger management skill in Class $X$ of SMK Muhammadiyah Mungkid was categorized as very high. However, some students were reported to lack anger management skills. Accordingly, school counselors' role is pivotal to help students improve their anger management skills. School counselors may provide guidance or counseling services. While the former could improve an individual's anger management skills, the latter could be implemented to handle students' problems related to anger management. School counselors may provide creative guidance and counseling services to improve students' anger management skills.

\section{REFERENCES}

Amin, R., Bibi, Z., \& Khawar, R.(2018). Impact of anger management training in reducing anger \& aggression among medical students. Rawal Medical Journal, 43(1).

Awaliyah, I. T. A., Taufiq, A., \& Hafina, A. (2019). The effectiveness of sociodrama to improve students' anger management skills. Islamic Guidance and Counseling Journal, 2(2), 56-65.

Bilge, A., \& Keskin, G. (2017). An evaluation of the effectiveness of anger management education enriched by psychodrama. Journal of Psychiatric Nursing/Psikiyatri Hemsireleri Dernegi, 8(2).

Cherry, M. \& Flanagan, O. (2017). The moral psychology of anger. London: Rowman \& Littlefield International Ltd.

Feindler, E. L. \& Engel, E. C. (2011). Assessment and intervention for adolescents with anger and aggression difficulties in school settings. Psychology in the Schools Journal, 48(3).

Hudaya, N. F. (2015). Peningkatan kemampuan mengelola emosi marah melalui teknik anger management pada peserta didik kelas $\mathrm{x}$ teknik komputer dan jaringan SMK Muhammadiyah 1 Moyudan. Jurnal Bimbingan dan Konseling, 4(1).

Kannis-Dymand, L., Salguero, J. M., Ramos-Cejudo, J., \& Novaco, R. W. (2019). Dimensions of anger reactions-revised (dar-r): validation of a brief anger measure in australia and spain. Journal of clinical psychology, 75(7), 12331248.

Lee, A. H. \& DiGiusppe, R. (2018). Anger and agression treatments: a review of meta-analyses. Current Opinion in Psychology Journal, 19.

Lotfali, S., Moradi, A., \& Ekhtiari, H. (2016). On the effectiveness of emotion regulation training in anger management and emotional regulation difficulties in adolescents. Modern Applied Science Journal, 11(1), 114.

Lök, N., Bademli, K., \& Canbaz, M. (2018). The effects of anger management education on adolescents' manner of displaying anger and selfesteem: A randomized controlled trial. Archives of Psychiatric Nursing Journal, 32(1), 75-81.

McClellan, J., Levitt, K., \& DiClementi, G. (2017). Emotional intelligence and positive organizational leadership: A conceptual model for positive emotional influence. Journal of Behavioral and Applied Management, 17(3), 2626.

Mokhber, T., Masjedi, A., \& Bakhtiari, M. (2016). The effectiveness of anger management training on decreasing the anger of unsupervised girl adolescents. Scientific Research Publishing Journal, 5.

Moore, C. C., Hubbard, J., Morrow, M. T., Barhight, L. R., Lines, M. M., Sallee, M., \& Hyde, C. T. (2019). The psychophysiology supporting children's constructive responses to peer provocation. Merrill-Palmer Quarterly Journal, 65(4), 447-463.

Nasir, R. \& Ghani, N A. (2014). Behavioral and emotional of anger expression and anger management among adolescent. Procedia-Social and Behavioral Sciences Journal, 140. 
Potter-Efron, R. T. (2015). Handbook of anger management and domestic violence offender treatment. New York: Routledge.

Pullen, L., Modcrin, M. A., Sandra, L., McGuire, Lane, K., Kearnely, M., \& Engle, S. (2015). Anger in adolescent communities: How angry are they?. Pediatric Nursing Journal, 41(3).

Rahayu, E. \& Soejuwinoto, P. (2017). Enhancing indonesian high school students' understanding on anger management. International Journal of Economic Perspectives, 11(1).

Rahmi, A. (2017). Penerapan model konseling islam dalam membantu kesadaran beragama pada remaja menjadi pribadi berakhlakul karimah. Jurnal Al-Taujih: Jurnal Bingkai Bimbingan dan Konseling Islami, 3(2), 29-38.

Reilly, P. M. \& Shopshire, M. S. (2019). Anger management for substance use disorder and mental health clients. Rockville: U. S. Department of Health and Human Services.

Sari, A. P. (2019). Cognitive-behavioral anger management training (CBAMT) untuk menurunkan perilaku agresi pada remaja awal. Persona: Jurnal Psikologi Indonesia, 8(2), 294-307.
Shahsavarani, A. \& Noohi, S. (2014). Explaining the bases and fundamentals of anger: a literature review. International Journal of Medical Reviews, 1(4).

Siddiqah, L. (2010). Pencegahan dan penanganan perilaku agresif remaja melalui pengelolaan amarah (anger management). Jurnal Psikologi, 37(1), 50-64.

Utami, R. R. \& Elfina, M. L. (2018). The influence of anger management on aggression behavior and peer acceptance as a mediation variable. Advances in Social Science, Education and Humanities Research (ASSEHR), 304.

Valizadeh, S., Davaji, R. B. O., \& Nikamal, M. (2010). The effectiveness of anger management skills training on reduction of aggression in adolescents. Procedia-Social and Behavioral Sciences Journal, 5.

Wigati, I. (2013). Teori kompensasi marah dalam perspektif psikologi islam. Ta'dib: Jurnal Pendidikan Islam, 18(02), 193-214.

Yunere, F., Keliat, B. A., \& Putri, D. E. (2019). Pengaruh pelaksanaan manajemen marah terhadap perilaku kekerasan pada siswa SMK. Jurnal Kesehatan Perintis (Perintis's Health Journal), 6(2), 153-163. 